\title{
Antifungal Activity of Essential Oil and Main Components from Mentha pulegium Growing Wild on the Chilean Central Coast
}

\author{
Iván Montenegro ${ }^{1}$, Bastián Said ${ }^{2}$, Patricio Godoy ${ }^{3}$, Ximena Besoain ${ }^{4}$, Carol Parra ${ }^{5}$,
} Katy Díaz ${ }^{6, *}$ and Alejandro Madrid ${ }^{7, *}$

1 Escuela de Obstetricia y Puericultura, Facultad de medicina, Universidad de Valparaíso, Angamos 655, Reñaca, Viña del Mar 2520000, Chile; ivan.montenegro@uv.cl

2 Departamento de Química, Universidad Técnica Federico Santa María, Av. Santa María 6400, Vitacura, Santiago 7630000, Chile; bastian.said@usm.cl

3 Instituto de Microbiología Clínica, Facultad de Medicina, Universidad Austral de Chile, Los Laureles s/n, Isla Teja, Valdivia 5090000, Chile; patricio.godoy@uach.cl

4 Escuela de Agronomía Pontificia Universidad Católica de Valparaíso, Quillota, San Francisco s/n La Palma, Quillota 2260000, Chile; ximena.besoain@pucv.cl

5 Laboratorio de Investigación en Nutrición y Alimentos (LINA), Departamento Disciplinario de Nutrición, Facultad de Ciencias de la Salud, Universidad de Playa Ancha, Valparaíso 2340000, Chile; carol.parra@upla.cl

6 Departamento de Química, Universidad Técnica Federico Santa María, Av. España N 1680, Valparaíso 2340000, Chile

7 Laboratorio de Productos Naturales y Síntesis Orgánica (LPNSO), Departamento de Química, Facultad de Ciencias Naturales y Exactas, Universidad de Playa Ancha, Avda. Leopoldo Carvallo 270, Playa Ancha, Valparaíso 2340000, Chile

* $\quad$ Correspondence: katy.diaz@usm.cl (K.D.); alejandro.madrid@upla.cl (A.M.); Tel.: +56-032-250-0526 (A.M.)

Received: 12 December 2019; Accepted: 6 February 2020; Published: 10 February 2020

Abstract: Fungal diseases, both pre- and post-harvest, are currently difficult to control—increased antifungal resistances have further stimulated the search for natural alternatives. The objective of the present research work was to evaluate the antifungal activities of Mentha pulegium essential oil (EO) and its major constituents. The EO was obtained from hydro distillation of fresh leaves, and composition was determined using gas chromatography/mass spectrometry (GC/MS). The main components were identified as pulegone (29.33\%), menthol (28.79\%), menthone (20.48\%), and isopulegol (9.75\%). $\mathrm{EO}$ and isopulegol exhibited the highest antifungal activity, with half maximal effective concentrations $\left(\mathrm{EC}_{50}\right)$ inhibiting mycelial activity of Monilinia fructicola at $24.6 \mu \mathrm{g} / \mathrm{mL}$ and $20.8 \mu \mathrm{g} / \mathrm{mL}$, respectively, and against Botrytis cinerea, at $301.45 \mu \mathrm{g} / \mathrm{mL}$ and $333.84 \mu \mathrm{g} / \mathrm{mL}$, respectively. These findings could lay the foundation for developing antifungal agents of agricultural value.

Keywords: Mentha pulegium; Botrytis cinerea; Monilinia fructicola; antifungal activity; essential oil

\section{Introduction}

Phytopathogenic fungi are a serious threat to plant health, causing a plethora of diseases that contribute substantially to overall losses in agricultural yield [1]. In addition, fungal plant pathogens are divided into two main groups: biotrophic pathogens, which form intimate interactions with plants and can persist in and utilize living tissues (biotrophs), and necrotrophic pathogens, which kill the tissue to extract nutrients (necrotrophs) [2]. Botrytis cinerea and Monilinia fructicola are the best examples of broad-host-range, necrotrophic plant pathogens. The success of these pathogens on diverse crops is attributed to the production of an extensive array of compounds, enzymes, and toxins, which singly or in combination likely interfere with common structural and functional features shared among different 
plant families [3]. For instance, B. cinerea can infect more than 235 different plant species prevalent over geographically diverse regions, causing grey mould [4], while $M$. fructicola can infect different members of the Rosaceae family worldwide, causing brown rot [5]. The losses generated by these fungi have led farmers to combat them mainly with chemical treatments, which cause harmful effects on human and environmental health, and may result in more resistant strains and an increase in production costs [6]. Recently, many researchers have demonstrated that essential oils (EOs), due to their effectiveness, low toxicity, and low persistence in the environment, should be used as a promising form of alternative to synthetic fungicides [7].

Mentha pulegium L. (known in Chile as poleo) is a medicinal flowering plant native to Chile, Europe, North Africa, and the Middle East [8] that grows wild in the temperate regions. Traditionally, Mentha pulegium has been extensively utilized in traditional herbal medicine to treat several ailments, including uses as a stomachic, expectorant, diuretic, menstrual treatment, and microbial infections [9]. Various biological properties for Mentha pulegium have been described, including antioxidant, antitumor, insecticidal, and antimicrobial activities [10-12]. The constituents of Mentha pulegium oil have been the subject of numerous studies, which have shown differences in its composition depending on the region of cultivation $[13,14]$.

Based on these considerations, the aim of this communication was to determine by means of in vitro antifungal activity bioassays the effectiveness of the Mentha pulegium EO and its chemical constituents against some important post-harvest diseases, such as Botrytis cinerea and Monilinia fructicola. The motivation behind this study is the wish to have natural substances that are active for possible organic control against the deterioration of fruits.

\section{Materials and Methods}

\subsection{Chemicals}

Pulegone, menthol, menthone, and isopulegol were obtained from Sigma-Aldrich, Darmstadt, Germany. All other chemicals used were analytical grade and obtained from either Sigma-Aldrich or Merck.

\subsection{Plant Material}

Leaves of Mentha pulegium were randomly selected and collected in March 2019 from the locality Laguna Verde, Valparaíso, Chile $\left(33^{\circ} 03^{\prime} 04^{\prime \prime} \mathrm{S}, 71^{\circ} 39^{\prime} 34^{\prime \prime} \mathrm{O}\right)$. The sample was stored as a voucher specimen MP2019-3.24 at the Natural Products Laboratory, University of Playa Ancha.

\subsection{EO Extraction and Analysis}

Essential oil was extracted from $500 \mathrm{~g}$ of fresh plant for $6 \mathrm{~h}$ by hydro distillation $\left(3.0 \mathrm{~L}, \mathrm{H}_{2} \mathrm{O}\right)$ in a Clevenger-type apparatus. The EO was dried over anhydrous sodium sulfate and stored at $-20^{\circ} \mathrm{C}$ until analysis. The EO component analysis was performed by gas chromatography (GC) and gas chromatography/mass spectrometry (GC/MS) using the instrumentation described below. A Thermo Scientific GC-MS system (GC: model Trace GC Ultra and MS: model ISQ, Thermo Fisher Scientific, Waltham, Massachusetts, USA) was used for the analysis of the sample. The separation was performed on a $60 \mathrm{~m} \times 0.25 \mathrm{~mm}$ internal diameter fused silica capillary column coated with $0.25 \mu \mathrm{m}$ film Rtx-5MS. The operating conditions were as follows: on-column injection; injector temperature, $250^{\circ} \mathrm{C}$; detector temperature, $280^{\circ} \mathrm{C}$; carrier gas, He at $1.25 \mathrm{~mL} / \mathrm{min}$; oven temperature program: $40^{\circ} \mathrm{C}$ for $5 \mathrm{~min}$, increase to $260^{\circ} \mathrm{C}$ at $5{ }^{\circ} \mathrm{C} / \mathrm{min}$, and then $260^{\circ} \mathrm{C}$ for $5 \mathrm{~min}$. The mass detector ionization employed an electron impact of $70 \mathrm{eV}$. Recording conditions employed a scan time of $1.5 \mathrm{~s}$ and a mass range of 40 to $400 \mathrm{amu}$. Compounds in the chromatograms were identified by comparison of their mass spectra with those in the NIST/EPA/NIH Mass spectral Library (2008), and by comparison of their retention index with those reported in the literature [15], for the same type of column or those of commercial standards (Sigma-Aldrich, Darmstadt, Germany). 


\subsection{In Vitro Antifungal Activity of the EO and Main Compounds against Phytopathogenic Fungi}

\subsubsection{Fungal Isolates}

The isolates of B. cinerea and M. fructicola were isolated directly from grape and peach sick fruits, respectively. The isolates were maintained on potato dextrose agar (PDA) medium in the dark at $22{ }^{\circ} \mathrm{C}$. Fungal isolates were characterized based on their morphology. It is part of the collection of micro-organisms of the Laboratory of Biological Tests of the Department of Chemistry of the University Technical Federico Santa María.

\subsubsection{In vitro Antifungal Activity}

The antifungal activity of the Mentha pulegium EO and main compounds against $B$. cinerea and $M$. fructicola were tested according to a procedure previously reported [16] using radial growth rate assay in potato dextrose agar (PDA) growth [16]. Fungal inocula of B. cinerea and M. fructicola were prepared in plates with potato dextrose agar (PDA), incubated for 3 days and 1 week, respectively, at $25^{\circ} \mathrm{C}$. The oil and main compounds were dissolved in an ethanol/water solution $(5 \% v / v)$ and were added to a Petri dish containing PDA medium (5 mL). The final tested concentrations were 10, 25, 50, 150 , and $250 \mu \mathrm{g} / \mathrm{mL}$ for each treatment. PDA medium containing $1 \%$ ethanol was considered as the negative control $\left(\mathrm{C}^{-}\right)$, whereas BC-1000 ${ }^{\circledR}$ and Mystic ${ }^{\circledR} 520$ SC, commercial fungicides $\left(\right.$ CHEMIE $^{\circledR}$, BAYER, Santiago, Chile), were used as the positive control $\left(\mathrm{C}^{+}\right)$at the same concentrations and under the same bioassay conditions. A mycelium agar disk (4 $\mathrm{mm}$ in diameter) of the pathogen's fungi were placed in the center of the PDA plates. B. cinerea was incubated for 3 days at $23^{\circ} \mathrm{C}$, whereas $M$. fructicola was incubated for 1 week at the same temperature in the dark. Each treatment was replicated three times. The inhibition percentages of mycelial growth for each compound were calculated and compared with the negative control as described in a previous report [17]. The effective concentration that inhibited mycelium growth by $50 \%\left(\mathrm{EC}_{50}\right)$ was obtained for each treatment by fitting \% Inhibition and concentration to a dose-response equation. The fit analysis was performed using the Origin 8.0 software [17].

\subsection{Statistical Analysis}

The data of Table $\mathrm{S} 1$ of the supplementary material and $\mathrm{EC}_{50}$ of Mentha pulegium $\mathrm{EO}$ and its main compounds were reported as the mean values \pm standard deviation (SD). The inhibition percentages of mycelial growth for oil and each compound were calculated and compared with the negative control as described in a previous report [16]. An analysis of variance (ANOVA) was performed on all data with a post-hoc Tukey HSD $(p \leq 0.05)$.

\section{Results and Discussion}

\subsection{Essential Oil Composition}

Hydrodistillation of Mentha pulegium aerial parts gave yellow EO in $1.30 \%$ yield $(\mathrm{w} / \mathrm{w})$. The chemical composition of the EO is given in Table 1.

Twelve components were identified in the essential oil: $50.11 \%$ were terpenketones, $46.89 \%$ terpenyl alcohols and derivatives, $1.81 \%$ terpenes, $0.37 \%$ linear alcohol, and $0.82 \%$ unknown compounds. The EO was mainly characterized by pulegone (29.33\%), menthol (28.79\%), menthone $(20.48 \%)$, and isopulegol $(9.75 \%)$ (see Figure 1).

The chemical composition of the Mentha pulegium EOs has been the subject of numerous studies, which show significant differences $[13,18]$. However, the chemical profile of the volatile oil of the studied plant was drastically different than previously reported. In our study, the oil of Mentha pulegium was found to contain equivalent amounts of pulegone and menthol. It is likely that these chemical variations are due to the diverse climatic and geographical differences between Mentha pulegium wild habitats in different countries as well as the divergent genetic potential of 
plants for compartmentalization of different biochemical pathways leading to a wide variety of oil components [19].

Table 1. Main components of Mentha pulegium essential oil (EO).

\begin{tabular}{cccccc}
\hline No. & Chemical Group & Main Components & \% Area $^{\mathbf{a}}$ & $\mathbf{R I}^{\mathbf{b}}$ & RIref $^{\mathbf{c}}$ \\
\hline 1 & Terpene & $\alpha$-Pinene & 0.20 & 940 & 941 \\
2 & Terpene & $\beta$-Pinene & 0.20 & 984 & 985 \\
3 & Linear alcohol & 3-Octanol & 0.37 & 993 & 993 \\
4 & Terpenyl alcohol & Isopulegol & 9.75 & 1147 & 1147 \\
5 & Terpenketone & Menthone & 20.48 & 1153 & 1154 \\
6 & Terpenyl derivative & Menthofuran & 1.06 & 1159 & 1160 \\
7 & Terpenyl alcohol & Menthol & 28.79 & 1176 & 1176 \\
8 & Terpenketone & Isopulegone & 0.30 & 1178 & 1179 \\
9 & Terpenketone & Pulegone & 29.33 & 1255 & 1257 \\
10 & Terpenyl derivative & Menthyl acetate & 8.35 & 1283 & 1283 \\
11 & Terpene & $\alpha$-Caryophyllene & 0.28 & 1477 & 1472 \\
12 & Terpene & Caryophyllene oxide & 0.07 & 1613 & 1606 \\
13 & & Unknown compounds & 0.82 & & \\
\hline
\end{tabular}

a Surface area of GC peak; ${ }^{b}$ RI: Retention indices relative to $C_{8}-C_{36} n$-alkanes on the Rtx-5MS capillary column ${ }^{c}$ RIref: Retention indices reported in literature.<smiles>CC(C)=C1CC[C@@H](C)CC1=O</smiles>

Pulegone<smiles>CC(C)[C@H]1CC[C@@H](C)C[C@H]1O</smiles>

Menthol<smiles>CC(C)[C@H]1CC[C@@H](C)CC1=O</smiles>

Menthone<smiles>C=C(C)[C@H]1CC[C@@H](C)C[C@H]1O</smiles>

Isopulegol

Figure 1. Structures of the main compounds present in the EO of M. pulegium.

3.2. In Vitro Antifungal Activity of the EO and Main Compounds on Mycelium Growth of Botrytis cinerea and Monilinia fructicola

In this investigation, Mentha pulegium EO exhibited different degrees of antifungal activity against B. cinerea and M. fructicola (Figure 2).
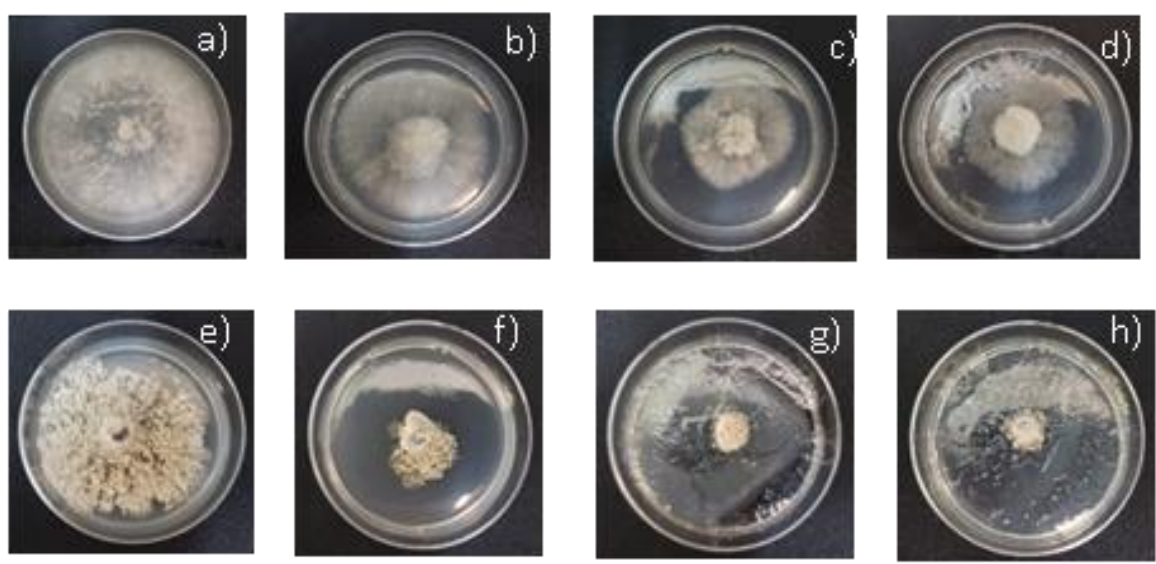

Figure 2. In vitro effect of Mentha pulegium $\mathrm{EO}$ on the mycelial growth of B. cinerea and M. fructicola according to different concentrations: (a) $0 \mu \mathrm{g} / \mathrm{mL}$ (Negative control); (b) $25 \mu \mathrm{g} / \mathrm{mL}$; (c) $250 \mu \mathrm{g} / \mathrm{mL}$; (d) BC-1000 ${ }^{\circledR} 25 \mu \mathrm{g} / \mathrm{mL}$ for B. cinerea; (e) $0 \mu \mathrm{g} / \mathrm{mL}$ (Negative control); (f) $25 \mu \mathrm{g} / \mathrm{mL}$; (g) $250 \mu \mathrm{g} / \mathrm{mL}$ (h) MYSTIC ${ }^{\circledR} 520 \mathrm{SC}$ at $25 \mu \mathrm{g} / \mathrm{mL}$, used as positive control for M. fructicola. 
The effect on mycelial growth is evaluated by comparing the growth areas with that observed for the negative control. The results are expressed as a percentage of inhibition, which is calculated as the ratio of the area of B. cinerea and $M$. fructicola in the presence and absence of the Mentha pulegium EO and main compounds, and they are summarized in Table S1 (Supplementary Material). In addition, $\mathrm{EC}_{50}$ values (concentration causing 50\% inhibition of mycelial growth) were obtained from fitting data to a dose-response curve. The comparison between antifungal effects of $\mathrm{EO}$ and natural compounds were further confirmed by comparing their effective concentrations for $\mathrm{EC}_{50}$ listed in Table 2.

Table 2. $\mathrm{EC}_{50}$ values of Mentha pulegium $\mathrm{EO}$ and its main compounds on the in vitro mycelial growth of B. cinerea and M. fructicola.

\begin{tabular}{ccccc}
\hline & \multicolumn{2}{c}{ B. Cinerea } & \multicolumn{2}{c}{ M. Fructicola } \\
\hline Treatment & ${ }^{*} \mathrm{EC}_{\mathbf{5 0}}(\mu \mathrm{g} / \mathrm{mL}) \pm^{* *} \mathrm{SD}$ & ${ }^{* * *} \mathbf{R}$ & ${ }^{*}$ EC $_{\mathbf{5 0}}(\mu \mathrm{g} / \mathrm{mL}) \pm^{* *} \mathrm{SD}$ & ${ }^{* * *} \mathbf{R}$ \\
\hline EO & $301.45 \pm 1.49^{\mathrm{a}}$ & 0.9541 & $24.6 \pm 1.33^{\mathrm{b}}$ & 0.8916 \\
Isopulegol & $333.84 \pm 2.00^{\mathrm{b}}$ & 0.9945 & $20.8 \pm 1.21^{\mathrm{a}}$ & 0.8638 \\
Menthone & $444.19 \pm 1.57^{\mathrm{c}}$ & 0.9801 & $53.4 \pm 1.36^{\mathrm{d}}$ & 0.9342 \\
Menthol & $332.15 \pm 2.27^{\mathrm{b}}$ & 0.9984 & $33.4 \pm 1.23^{\mathrm{c}}$ & 0.8800 \\
Pulegone & $496.48 \pm 1.40^{\mathrm{d}}$ & 0.9649 & $69.6 \pm 1.36^{\mathrm{e}}$ & 0.9228 \\
BC-1000 ${ }^{\circledR}$ & $238.28 \pm 2.04^{\mathrm{e}}$ & 0.7999 & - & - \\
Mystic $^{\circledR}$ 520 SC & - & - & $2.19 \pm 0.75^{\mathrm{f}}$ & 0.7999 \\
\hline
\end{tabular}

These values were estimated by measuring the colony diameter after of $72 \mathrm{~h}$ and $168 \mathrm{~h}$ of incubation. ${ }^{*} \mathrm{EC}_{50}$ : concentration causing 50\% mycelial growth inhibition; ${ }^{* *}$ SD: Standard Deviation; ${ }^{* * *}$ R: Pearson's correlation coefficient. Mean values followed by the different letters under different treatments within a column are significantly different to positive control at $p \leq 0.05$ according to Tukey test.

Table 2 showed that $\mathrm{EO}$ and isopulegol exhibited strong activity against $M$. fructicola, with $\mathrm{EC}_{50}$ values of $24.6 \mu \mathrm{g} / \mathrm{mL}$ and $20.8 \mu \mathrm{g} / \mathrm{mL}$, respectively, and moderate activity against $B$. cinerea, with $\mathrm{EC}_{50}$ values of $301.45 \mu \mathrm{g} / \mathrm{mL}$ and $333.84 \mu \mathrm{g} / \mathrm{mL}$, respectively. However, the $\mathrm{EC}_{50}$ values of $\mathrm{EO}$ and isopulegol are significantly different $(p \leq 0.05)$; EO is more active compared to isopulegol against $B$. cinerea but is less active against $M$. fructicola. Based on the $\mathrm{EC}_{50}$ values of the five treatments tested, $\mathrm{EO}$ and isopulegol are the most active growth inhibitors against both pathogens. Their $\mathrm{EC}_{50}$ values are significantly different with BC-1000 ${ }^{\circledR}$ and Mystic ${ }^{\circledR} 520$ SC as the positive controls.

On the other hand, this is the first report of isopulegol activity against these phytopathogenic fungi. Furthermore, the results indicate that menthone and pulegone presented slight inhibitory effects on $B$. cinerea, in accordance with previous reports [20,21]. Menthol showed inhibitory effects on both, although with a slightly higher inhibition against $M$. fructicola, which agrees with previous findings [21-23]. In general, the results of the inhibitory effect of Mentha pulegium oil is consistent with previous reports on the antifungal activity of essential oils, which showed that the inhibitory effects of essential oils tend to increase according to their major component as follows: phenols $>$ alcohols $>$ aldehydes $>$ ketones $>$ ethers $>$ hydrocarbons [24]. Numerous literature studies have provided support for the antimicrobial activities of several of the compounds in Mentha pulegium oil [25]. For instance, terpene alcohols (isopulegol and menthol) have shown greater inhibition of mycelial growth than have terpene ketones (menthone and pulegone) against both pathogens. Moreover, other authors have similarly found that terpene alcohols tend to be relatively active, regardless of structural types, as a function of their hydrogen capacity and water solubility [26].

The research team expects to expand upon the most active compounds found in this study, which are promising candidates for structural modification, as starting materials for potent antifungal hybrids against globally important agricultural pathogens.

\section{Conclusions}

Overall, the evaluation of Mentha pulegium EO against the two most important fruit diseases responsible for the most post-harvest losses revealed that the essential oil and its main components 
were moderate growth inhibitors. Activities toward the two pathogens differed slightly, with higher inhibition against $M$. fructicola. Our results suggest that the antifungal activity of the oil is due to the synergistic effect of the components, including some not examined thus far. In turn, Mentha pulegium oil may be potentially used in natural therapies to treat infectious diseases in plants, and its inhibitory abilities help confirm the ability of some terpenes—in our case, isopulegol and menthol— to inhibit $M$. fructicola at low concentrations. In addition, we highlighted that mixtures of isopulegol and menthol could represent a promising starting point for the development of antifungal agents. Combinations of these two substances in various ratios should be studied, and it will be enlightening to evaluate the interaction effects of either or both isopulegol and menthol with commercial fungicide.

Supplementary Materials: The following are available online at http://www.mdpi.com/2073-4395/10/2/254/s1, Table S1. Effect of on in vitro mycelial growth of B. cinerea and M. fructicola measured as a percentage of inhibition.

Author Contributions: A.M. supervised the whole study. B.S. collected the plant. X.B. performed the isolation of the EO. C.P. and P.G. performed the spectroscopic data. K.D. conceived and designed the biologic experiments. A.M., K.D., and I.M. collaborated on the discussion and interpretation of the results. K.D. and A.M. wrote the manuscript. All authors have read and agreed to the published version of the manuscript.

Funding: This research was funded by FONDECYT (grant No. 1190424).

Acknowledgments: The authors thank sincerely Patricio Novoa for the identification of the plant.

Conflicts of Interest: The authors declare no conflict of interest.

\section{References}

1. Chandrasekaran, M.; Thangavelu, B.; Chun, S.C.; Sathiyabama, M. Proteases from phytopathogenic fungi and their importance in phytopathogenicity. J. Gen. Plant Pathol. 2016, 82, 233-239. [CrossRef]

2. Doehlemann, G.; Ökmen, B.; Zhu, W.; Sharon, A. Plant Pathogenic Fungi. Microbiol. Spectr. 2017, 5, 703-726.

3. Laluk, K.; Mengiste, T. Necrotroph Attacks on Plants: Wanton Destruction or Covert Extortion? Arab. Book 2010, 8, e0136. [CrossRef]

4. Boddy, L. Pathogens of Autotrophs. In the Fungi, 3rd ed.; Watkinson, S., Boddy, L., Money, N., Eds.; Elsevier Ltd.: London, UK, 2016; Volume 3, pp. 245-291.

5. Hrustić, J.; Mihajlovic, M.; Grahovac, M.; Delibašić, G.; Bulajic, A.; Krstic, B.; Tanović, B. Genus Monilinia on pome and stone fruit species. Pestic. Fitomedicina 2012, 27, 283-297. [CrossRef]

6. The Future of Food and Agriculture-Trends and Challenges; FAO: Rome, Italy, 2017; Available online: http: //www.fao.org/3/a-i6583e.pdf (accessed on 22 November 2019).

7. El Ouadi, Y.; Manssouri, M.; Bouyanzer, A.; Majidi, L.; Bendaif, H.; Elmsellem, H.; Shari-ati, M.A.; Melhaoui, A.; Hammouti, B. Essential oil composition and antifungal activity of Melissa officinalis originating from north-Est Morocco, against postharvest phytopatho-genic fungi in apples. Microb. Pathog. 2017, 107, 321-326. [CrossRef] [PubMed]

8. Stengele, M.; Stahl-Biskup, E. Seasonal variation of the essential oil of european pennyroyal (Mentha pulegium L.). Acta Hortic. 1993, 344, 41-51. [CrossRef]

9. Minsal. MHT: Medicamentos Herbarios Tradicionales: 103 Especies Vegetales. Santi-ago, Chile. 2009. Available online: https://www.minsal.cl/wp-content/uploads/2018/02/Libro-MHT-2010.pdf (accessed on 22 November 2019).

10. Abdelli, M.; Moghrani, H.; Aboun, A.; Maachi, R. Algerian Mentha pulegium L. leaves es-sential oil: Chemical composition, antimicrobial, insecticidal and antioxidant activities. Ind. Crop Prod. 2016, 94, 197-205. [CrossRef]

11. Teixeira, B.; Marques, A.; Ramos, C.; Batista, I.; Serrano, C.; Matos, O.; Neng, N.R.; Nogueira, J.M.; Saraiva, J.A.; Nunes, M.L. European pennyroyal (Mentha pulegium) from Portugal: Chemical composition of essential oil and antioxidant and antimicrobial properties of extracts and essential oil. Ind. Crop. Prod. 2012, 36, 81-87. [CrossRef]

12. Tapondjou, L.A.; Adler, C.; Bouda, H.; Fontem, D.A. Efficacy of powder and essential oil from Chenopodium ambrosioides leaves as post-harvest grain protectants against six-stored product beetles. J. Stored Prod. Res. 2002, 38, 395-402. [CrossRef] 
13. Stoyanova, A.; Georgiev, E.; Kula, J.; Majda, T. Chemical Composition of the Essential Oil of Mentha pulegium L. from Bulgaria. J. Essent. Oil Res. 2005, 17, 475-476. [CrossRef]

14. El-Ghorab, A.H. The Chemical Composition of the Mentha pulegium L. Essential Oil from Egypt and its Antioxidant Activity. J. Essent. Oil Bear. Plants 2006, 9, 183-195. [CrossRef]

15. Adams, R.P. Identification of Essential Oil Components by Gas Chromatography/Mass Spectrometry, 4th ed.; Allured Publishing Corporation: Carol Steam, IL, USA, 2007.

16. Mellado, M.; Espinoza, L.; Madrid, A.; Mella, J.; Chávez-Weisser, E.; Diaz, K.; Cuellar, M. Design, synthesis, antifungal activity, and structure-activity relationship studies of chalcones and hybrid dihydrochromane-chalcones. Mol. Divers. 2019,1-13. [CrossRef]

17. Olea, A.F.; Espinoza, L.; Sedan, C.; Thomas, M.; Martínez, R.; Mellado, M.; Carrasco, H.; Díaz, K. Synthesis and In Vitro Growth Inhibition of 2-Allylphenol Derivatives Against Phythopthora cinnamomi Rands. Molecules 2019, 24, 4196. [CrossRef]

18. Piras, A.; Porcedda, S.; Falconieri, D.; Maxia, A.; Gonçalves, M.; Cavaleiro, C.; Salgueiro, L. Antifungal activity of essential oil from Mentha spicata L. and Mentha pulegium L. growing wild in Sardinia island (Italy). Nat. Prod. Res. 2019, 1-7. [CrossRef]

19. Hassanpouraghdam, M.; Akhgari, A.; Aazami, M.; Emarat-Pardaz, J. New menthone type of Mentha pulegium L. volatile oil from northwest Iran. Czech J. Food Sci. 2011, 29, 285-290. [CrossRef]

20. Bouchra, C.; Achouri, M.; Hassani, L.I.; Hmamouchi, M. Chemical composition and antifungal activity of essential oils of seven Moroccan Labiatae against Botrytis cinerea Pers: Fr. J. Ethnopharmacol. 2003, 89, 165-169. [CrossRef]

21. Tsao, R.; Zhou, T. Antifungal Activity of Monoterpenoids against Postharvest Pathogens Botrytis cinerea and Monilinia fructicola. J. Essent. Oil Res. 2000, 12, 113-121. [CrossRef]

22. Rosslenbroich, H.-J.; Stuebler, D. Botrytis cinerea-History of chemical control and novel fungicides for its management. Crop. Prot. 2000, 19, 557-561. [CrossRef]

23. Angelini, R.M.D.M.; Abate, D.; Rotolo, C.; Gerin, D.; Pollastro, S.; Faretra, F. De novo assembly and comparative transcriptome analysis of Monilinia fructicola, Monilinia laxa and Monilinia fructigena, the causal agents of brown rot on stone fruits. BMC Genom. 2018, 19, 436.

24. Dambolena, J.; Lopez, A.; Canepa, M.; Theumer, M.; Zygadlo, J.; Rubinstein, H. Inhibitory effect of cyclic terpenes (limonene, menthol, menthone and thymol) on Fusarium verticillioides MRC 826 growth and fumonisin B1 biosynthesis. Toxicon 2008, 51, 37-44. [CrossRef]

25. Luna, E.C.; Luna, I.S.; Scotti, L.; Monteiro, A.F.M.; Scotti, M.T.; De Moura, R.O.; De Araújo, R.S.A.; Monteiro, K.L.C.; De Aquino, T.M.; Ribeiro, F.F.; et al. Active Essential Oils and Their Components in Use against Neglected Diseases and Arboviruses. Oxidative Med. Cell. Longev. 2019, 2019, 1-52. [CrossRef] [PubMed]

26. Griffin, S.G.; Markham, J.L.; Leach, D.N. An Agar Dilution Method for the Determination of the Minimum Inhibitory Concentration of Essential Oils. J. Essent. Oil Res. 2000, 12, 249-255. [CrossRef]

(C) 2020 by the authors. Licensee MDPI, Basel, Switzerland. This article is an open access article distributed under the terms and conditions of the Creative Commons Attribution (CC BY) license (http://creativecommons.org/licenses/by/4.0/). 